\title{
Migrant Remittances and Skipped Generation Households: Investigating the Exchange Motive Using Evidence from Nang Rong, Thailand
}

\author{
Martin Piotrowski \\ University of Oklahoma
}

\begin{abstract}
Using data from the Nang Rong projects social survey ( $N=6,801$ households) and qualitative data from semi-structured interviews, I examine the relationship between migrant remittances and the skipped generation household structure. I find that the skipped generation household is a significant determinant of in-kind remittances and the amount of remittances received by the household. Surprisingly, although qualitative data suggest that grandparents living in skipped generation households provide childcare for the children of absent migrants, quantitative evidence reveals that these households receive lower remittance amounts than other households. This suggests that although an exchange motivation may be overlooked in the remittance literature, it does not apply to migrant remittances as it does in the broader literature on inter vivos intergenerational transfers.
\end{abstract}

\section{Introduction}

Migrant remittances involving transfers of money and goods from migrants to their origin households are an important source of income and poverty alleviation for migrants, their households, and their origin communities in many parts of the developing world. International remittances constitute one of the largest and most stable sources of money for developing economies, often exceeding international aid (Kapur and McHale, 2003; Taylor, 
1999; World Bank, 2006). Considering the large number of internal migrants throughout the world (IOM, 2005; Roberts, 1997), remittances from these migrants probably also constitute substantial amounts of money.

While migrant remittances and the underlying motivations for their transfer have been the subject of many studies, changes in migration patterns over the past several decades favoring the movement of women have altered household arrangements, creating important implications for remittance patterns. In particular, a growing body of literature in developing countries documenting "transnational motherhood," and the internal migration of women suggests the increasing incidence of children left behind in the care of surrogate caregivers (Dreby, 2006; Hondagneu-Sotelo and Avila, 1997; Hirsch, 2003; Salazar Parreñas, 2005; Schmalzbauer, 2004). These children of migrating parents reside in "skipped generation" households, in which grandparents are the primary care providers for their grandchildren, and neither parent is present (Casper and Bryson, 1998).

Using a mixed-methods approach and data from a sample of households $(N=6,801)$ from Nang Rong, Thailand, I examine the skipped generation household as a determinant of migrant remittances. I argue that the remittance literature has been slow to consider quid-pro-quo exchanges as a motivation guiding migrants' intentions for sending remittances. While the theoretical framework underlying much of the research on monetary and material transfers between family members identifies exchange as an underlying motive, there is little empirical work in the remittance literature on the subject.

I attempt to fill this gap in the literature by suggesting that the association between remittances and the skipped generation household represents an opportunity for migrants to send money in exchange for time that extended relatives spend engaged in childcare for the children of absent migrant parents. I examine this process in a rural agrarian setting experiencing rapid social, economic, and demographic change (including a high incidence of migration). In what follows, I consider the theoretical and empirical literature on migrant remittances, and the rationale for studying exchange as an underlying motivation for remittances.

\section{Review of the Literature}

The New Economics of Labor Migration, perhaps the leading approach to studying migrant remittances, views remittance transfers as part of a household decision-making strategy to reduce risk and increase investment opportunities in areas where credit, insurance and capital markets are absent or imperfect (Massey et al., 1993; Taylor and Martin, 2001). According to this view, migrants send remittances to agricultural origin house- 
holds to insure then from risks associated with droughts, floods, blights or famines (Stark and Lucas, 1988). In the absence of credit markets, migrants also act as financial intermediaries alleviating capital constraints and creating investment opportunities for financing new farm technology or funding a family business (Stark, 1991).

There are many similarities between the remittance literature and a broader literature on intergenerational exchanges, and both can be viewed from the perspective of the New Home Economics (e.g., Becker, 1993). In both literatures, the household is seen as the fundamental decision-making unit involving inter vivos ${ }^{1}$ transfers. Also, in both literatures, transfers follow from either repayment of prior investment in education (Brown and Poirine, 2005; Stark and Lucas, 1988; Lee et al., 1994; Lillard and Willis, 1997; Lin et al., 2003), enticements of strategic inheritance bequests (Bernheim et al., 1985; de la Brière et al., 2002; Hoddinot, 1994; VanWey, 2004), or insurance transfers sent in times of crisis (Amuedo-Dorantes and Pozo, 2006; Frankenberg et al., 2002; Yang and Choi, 2007). The underlying motivations for these transfers include bargaining and altruism (Becker, 1993; Chaippori, 1992; Stark, 1984).

In the intergenerational support literature, there is yet another motivation for transfers. This is the exchange motive (Cox et al., 1987), which involves payment of money for time given with help in day-to-day tasks such as childcare or help with housework (Frankenberg et al., 2002; Lillard and Willis, 1997; Secondi, 1997). Despite the similarities between the intergenerational support and the remittance literatures, the latter has been slow to incorporate exchange as an underlying motive. Yet, in many contexts, exchange can be an important motivation for remittances. For example, in areas where parents migrate away, leaving their children in the care of relatives, family members living in the migration origin household provide a considerable service to migrants by caring for their children. Such children reside in a skipped generation household, and the possibility for remittances to be exchanged for childcare provision is high.

Much of the literature on childhood separation from parents in developing countries has focused on a household division of labor inherent in the skipped generation household, in which extended kin perform reproductive labor (i.e., caring for children in the parents' absence) while the parental generation perform productive labor, earning money to support those left behind (Bledsoe and Isiugo-Abanihe, 1989; Peterson, 1993; Richter, 1996; Lee, 2000; Schroder-Butterfill, 2004). Freedom from childcare responsibili-

\footnotetext{
${ }^{1}$ Inter vivos refers to exchanges made within one's lifetime, in distinction to inheritance
} transfers made after one's death. 
ties allows parents to migrate as target earners, who send remittances back to the origin household.

Skipped generation households have been observed in international as well as internal migration sending regions. Although there are differences in the determinants and circumstances stemming from each type of migration (for example legal barriers to migration or transportation costs), there are also parallels and common themes. Both are associated with structural inequalities between migration sending and receiving regions. In sending regions, poverty and job scarcity act as push factors encouraging young migrant parents to leave. In receiving regions, job availability and a demand for migrant labor act as pull factors.

In the context of internal migration, structural inequalities are associated with a shift from a rural agrarian to an urban industrial economy (Richter, 1996). In historical and contemporary pre-industrial settings, there was little concern of discernible loss of productivity or danger to children related to agricultural labor. Care for children was balanced with productive labor by combining non-mechanized agriculture and piecework with child supervision (Degler, 1980; Roos, 1985; Stycos and Weller, 1967). ${ }^{2}$

As industrialization proceeded, societies experienced a number of interrelated changes and dislocations that made it more difficult to maintain this balance (Brewster and Rindfuss, 2000; Presser 1986; Rindfuss et al., 2003; Weller, 1977). Worksites in manufacturing and service industries located at a distance from the home (usually in cities) force many to commute or even migrate away in order to participate in the labor force. Work schedules set by employers lacked the flexibility required for raising children. Modern mechanized workplaces pose many dangers to young children's safety, and the presence of children at work jeopardized productivity. This made it necessary to care for children away from the workplace (Brewster and Rindfuss, 2000).

Formal childcare options, themselves the product of economic transition, remain underdeveloped or out of reach for relatively poor, transient urban migrants. Yet, parents who desire to participate in an industrial economy cannot migrate (or remain migrants) if they do not have someone with whom to leave the children. Thus, parents facing the prospect of migration and separation from their children have to find substitute care providers. In many contexts, parents choose to leave their children with relatives, especially the maternal grandmother (Hashimoto, 1991; Hondagneu-Sotelo and Avila, 1997; Knodel and Saengtienchai, 2007;

\footnotetext{
${ }^{2}$ For an alternative view that sees balancing work and childrearing responsibility as more challenging see Desai and Jain (1994).
} 
Richter et al., 1992; Richter, 1996; Schmalzbauer, 2004; Schoder-Butterfill, 2004), a choice rooted in cultural tradition and strategic availability.

Childcare provided by extended relatives was historically common in developed countries, and still exists throughout the developing world, even for parents who are not migrants (Chen et al., 2000; Hermalin et al., 1998). It is easy to see, therefore, that childcare provided by extended kin could be a vital service for migrating parents, especially in contexts characterized by rapid urbanization and industrialization where local wage opportunities are limited. To understand how remittances and skipped generation household structures are related within such a setting, I describe Nang Rong, Thailand, the backdrop for this paper. I focus on the household economy, migration patterns, and available childcare options for migrating parents.

\section{The Setting}

Nang Rong is an agrarian district located in Buriram province, Northeast Thailand, near the Cambodian border. The district was a frontier region during the first six decades of the $20^{\text {th }}$ century (Entwisle et al., 1998; Rindfuss et al., 2007). Following the closing of the frontier, road construction, electrification, telecommunications improvements and migration substantially changed the way of life there (Curran, 1995).

Rain-fed paddy rice cultivation is central to the economy and most Nang Rong residents are poor subsistence farmers who sell only their excess yields. Some grow upland cash crops like cassava for export to foreign markets (Curran, 2005). Households usually farm small plots located in agricultural fields surrounding nucleated villages. Although some industrial development in the district has led to scattered industry, the level of non-agricultural employment remains low (VanWey, 2003). Many households supplement agricultural activities by participating in cottage industries such as silk weaving, silk worm raising, mat weaving, or other such activities. A few operate small stores or businesses. While a few local wage positions are available, wages are lower compared to potential earnings in cities like Bangkok. Consequently, many villagers choose to migrate away from the district.

Out-migration in Nang Rong is common. Indeed, migration rates in the Northeast region are higher than other major regions in Thailand (Goldstein, 1987; Chamratrithirong et al., 1995; Pejaranonda et al., 1995). My discussions with villagers suggest that poverty, job scarcity, debt, and the shift to a money economy motivate young people to leave rural villages in search of better-paying jobs on construction sites and factories. Migrants head to both rural and urban destinations (Chamratrithirong et al., 1995; VanWey, 2004). The former is thought to be associated with marriage while the latter 
is for labor. Most migration is within Thailand, although a few people travel abroad to countries like Taiwan, South Korea or the Gulf States. Major destinations for urban migrants include Bangkok, the Eastern Seaboard (a development region south of Bangkok), and Korat (a.k.a., Nakhon Ratchasima) the largest provincial city in Buriram. Much migration in Nang Rong is seasonal or circular, which is linked to labor demand fluctuations related to the agricultural cycle (Chamratrithirong et al., 1995; Richter et al., 1997).

Preliminary results using the Nang Rong data shows that migration is selective of young adults (roughly in the ages 15-39 in 2000, who make up almost 87 percent of all migrants). Work in Nang Rong by Rindfuss (1991) notes that young adults are conspicuously absent in rural villages. Those present include only middle-aged and elderly adults, as well as the small children of absent young adults. The ostensible absence of young people exists in other parts of the Northeast as well (Phongphit and Hewison, 2001). The 1990 Thai Census shows that compared with other migration flows throughout Thailand, a far smaller portion of rural-to-urban migrants are children (Pejaranonda et al., 1995). This may suggest that parents who migrate from rural villages to cities do so alone, while their children remain in rural villages. It is also possible that migrants leave their villages, marry and have children, and send children back to live with relatives in rural areas as suggested by Jampaklay (2006) and Richter (1996).

Traditionally, childcare from maternal relatives was common, as Northeast Thai newlyweds practiced matrilocal postnuptial customs whereby they moved in with the wife's family for a short time following marriage (Limanonda, 1995; Limanonda and Kowantanakul, 2002; Tan, 2002). Most of the villagers with whom I spoke said it was common for migrating parents to leave their children in the care of maternal relatives, especially the child's maternal grandmother.

Nang Rong parents have limited childcare options if they choose to migrate, and evidence suggests that formal childcare institutions in cities and non-relative care are not popular choices (Richter et al., 1992; Richter, 1996). Richter's qualitative data from a sample of Bangkok mothers found a high degree of conflict and distrust of non-relative childcare. Perhaps because formal care was new during the period of Richter's study, only a few respondents actually used such facilities, and some described neglect and poor quality care in these settings. It is likely that the added expense of formal childcare is prohibitive for many migrants, and that their effectiveness as target earners would be reduced if they did not take advantage of relatively inexpensive childcare from extended relatives living in origin communities. 


\section{Basic Approach}

To understand the connection between the skipped generation household and receipt of remittances by migration origin households, I use insights from a combination of semi-structured qualitative interviews, descriptive statistics and regression models. The dependent variables include measures of remittances, detailing the sending of monetary and in-kind remittances and the amount of monetary remittances sent. I limit remittances to only those sent by migrants who have moved outside of Nang Rong district, for a period of at least one year. Doing so ensures that migrants have moved sufficiently far that they cannot themselves care for their children. It also ensures that they are gone for a sufficiently long time to be able to generate enough money to send remittances.

The main independent variable is a measure of whether the household has a skipped generation structure. I expect that, everything else being equal, such households should be more likely to receive remittances (both money and in-kind) and should receive higher amounts of remittances. This expectation relates to the idea that relatives receive remittances in exchange for time providing childcare to children of absent migrants. To separate the effect of the skipped generation household from other factors related to remittances, I control for measures of household demographics indicating the family's dependency burden, such as separate variables for the number of people of non-working (13 and younger and 50 and older) and working age (14-49), ${ }^{3}$ and the number of migrants. I also include measures of the household economy, such as indications of alternative wage-generating activities (cottage industries, local factory labor income, raising of animals for sale or barter, growing cassava), uses of income (e.g., paying for labor for rice, cassava, or sugar cane harvesting and purchase of herbicides and pesticides), and physical capital (e.g., household wealth and land holdings). I also consider the household's susceptibility to risk of crop loss from flooding or drought.

One problem with examining the independent effect of the skipped generation structure on the household's receipt of remittances is that both the receipt of remittances and the formation of the skipped generation structure are related to the migration decision of parents. Consequently, the skipped generation structure may not have an exogenous effect on remittance receipt. To address this issue, I estimate a series of recursive models

\footnotetext{
${ }^{3}$ Prior fieldwork in Nang Rong suggests that rural farmers in this region begin to experience physical wear and tear, making it difficult to continue doing demanding physical labor much beyond their 50 s.
} 
in which I jointly estimate the determinants of remittance outcomes and of the skipped generation household. In these models, the skipped generation structure is used as a dependent variable in its own equation, as well as an independent variable for the remittance equations. As shown by Greene (2003), despite the endogeneity of the skipped generation variable in the remittance equations, this modeling approach yields consistent results.

As determinants of the skipped generation structure, I include measures of household demographics, such as the number of men and women of working age (14-49) and age 50 or older. Fieldwork suggests that grandparents of children of migrating parents are generally in their 50s. Therefore, having household members of this age should make it more likely that a skipped generation household will form, particularly if there are women in this age range. This is because maternal grandmothers are especially likely to care for the children of absent migrants. I control for working age household members to account for the possibility that aunts or uncles residing in the household also help with childcare. I also control for measures of demographic characteristics of migrants, using counts disaggregated by sex and marital status. Given that marriage signifies the beginning of family formation for many Thais, the number of married migrants (both males and females) ought to be positively related to the skipped generation household structure.

Measures of household agricultural involvement (i.e., animal husbandry and rice cultivation) and of household wealth are also included in the model. The former is included to account for factors that may interfere with household members' ability to raise children of absent migrants. The latter controls for differences in socioeconomic status that could influence the likelihood of leaving children with extended relatives.

To identify the skipped generation equation, I include a variable that affects the formation of the skipped generation household, but is exogenous to the remittance equation. For such a variable, I use a measure of the number of married women residing in the household, who are younger than 50, who use one of the following forms of contraception: oral contraceptive (the pill), intrauterine device (IUD), condom or injection. It is unlikely that contraceptive use causes households to receive remittances. ${ }^{4}$ Moreover, the use of contraception among migrant women is likely to reduce childbearing, and thus the formation of a skipped generation household.

Unfortunately, data on migrant women's contraceptive choices are not available. However, research on contraceptive choice in Nang Rong by

\footnotetext{
${ }^{4}$ The World Health Organization reports that family planning programs in Thailand that provide contraceptives are extensive (even available in parts of rural Thailand), convenient, and largely free of charge (WHO 2009).
} 
Godley (2001) and Entwisle et al. (1996), argues that the choice of method (including the choice not to use any method) is influenced by social network connections to friends or kin. As origin households anchor migrant networks, and provide an ongoing source of information to migrants (Roberts and Morris, 2004), it is reasonable to suspect that migrant women develop similar contraceptive practices to those found among women in their origin households.

The analysis is well suited to investigate the association between the skipped generation household and remittances as an indication of an exchange motivation. The data contain detailed information on a number of households, making it possible to examine the influence of the skipped generation pattern net of several other factors. Also, qualitative data aid in the interpretation of results, overcoming some of the shortcomings of a purely quantitative approach. Furthermore, the data have measures of both in-kind and monetary remittances. It is interesting to examine both, since they may represent a different level of awareness for the needs of the household. While money is a fungible asset that can be used to purchase any number of goods and services, transfers of such in-kind goods as food, clothing and appliances may be responsive to the particular needs of the home household. Specifically, migrant parents may provide food or clothing for their children.

The analysis also has some limitations. First, the approach cannot rule out altruism or bargaining motivations as alternatives to exchange. However, my intention is not to suggest that exchange is the only motivation for remittances. Rather, it is to suggest that it is an overlooked motivation that should be more prominently considered in the remittance literature. Second, the quantitative data do not contain explicit measures of childcare provided by household members. I make up for this shortcoming by drawing on my qualitative data, which are aimed in part at understanding the nature of care provided by grandparents and other relatives. These data provide broad evidence that grandparents become primary care providers for children of absent parents. Third, because of the way the data were collected, some people who the household considers to be migrants are not counted as such in the data. Most likely, an undercount of these individuals will reduce the remittance effect, but this effect should not be substantial.

Another shortcoming relates to the effect of past remittances. Remittances received by the household prior to the period under study may have funded ventures that became major sources of household income. Since measures of income-generating activities are included on the right-side of the remittance equation, their inclusion could lead to endogeneity bias if such past remittances are not taken into account. To address this issue, I conduct a sensitivity analysis in which I estimate all models with the 
inclusion of another independent variable that measures the amount of remittances received in the previous panel (1994). Unfortunately, not all households were eligible to receive such remittances, due to the way that migration was defined for the purposes of data collection. As such, the models that include this extra measure of remittances must use a different sample than the analytical sample. I acknowledge that dissimilar results across models could be due to differences in the sample or in model specification. I address this issue further in the results and conclusion sections, and I include more details about the definition of migration used in data collection in the subsequent section.

\section{Data and Sample}

Quantitative data come from the 2000 wave of the Nang Rong Projects Social Survey. Data on various social and demographic characteristics were collected in three successive data panels (1984, 1994 and 2000). At each wave, a complete census was conducted of all households in the original 51 villages, sampled within the Nang Rong district. Using a key informant from each household, data were obtained on all household members in residence, as well as proxy reports for any former household members living outside of the household. Information was collected on socio-demographic characteristics of each household member, the migration and remittance behavior of migrants, and about characteristics of the household itself, such as its farming activities and ownership of various assets.

The analytical sample includes 6,801 households. The Nang Rong household survey only obtained data on migration and remittances from households having records on two consecutive panels. This is because the survey defined migration as a change in residence between panels. Migrants are defined as any living individuals, about whom information was collected on a previous panel, who were living away from their origin village for two or more continuous months. As only households having data from the previous panel could potentially have migrants, only these households existing in the 1994 and 2000 panels are included in the analytical sample. Therefore, households included in the sample are not representative of all Nang Rong households. In particular, they are less representative of younger, newly formed households and those that moved into the district most recently. For the sensitivity analysis using the measure of past remittances (in 1994), I follow the same logic, and further limit the sample to households having data on all prior panels (i.e., 1984 and 1994; $N=4,430$ ). I also limit the analytical sample to only those having complete data on all variables used in the analysis. Using listwise deletion, I eliminated 33 
households having missing data. These households represent less than one percent of the original sample, and should have a negligible effect on results.

Data for the qualitative portion come from semi-structured interviews conducted in Nang Rong villages in February 2005. Seven villages throughout Nang Rong district were selected on a non-probability basis as sites for data collection. These villages were chosen with the intention of capturing variability in village contexts (e.g., distance to the nearest town, the presence of international migrants, distance to irrigation canals and the cultivation of cash crops). Interview subjects were recruited using a combination of convenience and snowball sampling. The qualitative data are not intended to be representative of the entire population of Nang Rong, rather they were selected to provide insights into the interpretation of quantitative results.

Qualitative interviews targeted individuals who had experienced childcare arrangements involving migrant parents living away from children. Villagers who were otherwise knowledgeable about such arrangements were also interviewed. A total of 41 interviews were conducted with the following: seven village headmen, two village officials knowledgeable about childcare (a public health worker and a nursery school teacher), 26 relatives (mostly maternal grandmothers) caring for the children of absent migrants, three former migrants whose children were cared for by relatives, two parents whose spouses were migrants, and one non-kin childcare provider.

\section{Measures}

Using household survey items which asked whether individual migrants sent any money or goods to the household within the last 12 months, I measure remittances in three ways: 1) as a dummy variable indicating whether any monetary remittances were received by the household, 2) as a similar variable for whether in-kind remittances were received, or 3 ) as the amount of monetary remittances sent. In-kind remittances include transfers of clothing, food (priced 100 baht $^{5}$ or more), electrical appliances, household goods or vehicles. The amount send was measured in broad categories to reduce recall error. The categories (in baht) include: no money, 1-1000, 10013000, 3001-5000, 5001-10000, 10001-20000, 20001-40000, 40001 and over. Following work by Hull (2007) and Piotrowski (2008), I constructed an overall measure of the amount of remittances sent to the household by taking the midpoint of each category and summing it over all migrants.

\footnotetext{
${ }^{5}$ The baht is the Thai unit of currency. In 2000, 1 baht equaled approximately 40 USD.
} 
The skipped generation household is measured as a dichotomous variable for whether both of the parents of any child (defined as someone aged 13 or younger) residing in the household were absent. Information on parents' residence was taken from their records on the household census roster. In the event that parents were not listed on the roster, additional information was taken from a variable which collected information about the location of the parents of each individual listed on the roster. Note that if members of the parental generation (such as siblings) live in the household, I still consider the household to have a skipped generation structure.

Turning to measures of control variables, I only describe select variables, as measures for the remaining variables are straightforward and selfexplanatory. Household demographic counts of working and non-working age people are constructed from household roster records of individuals residing in the household. Counts of additional household migrants are also constructed in this way, but include members who wereliving outside of the village for two or more consecutive months at the time of the survey (i.e., they are defined using the same definition used in the household survey).

The measure of involvement in cottage industries is a dichotomous variable for whether anyone in the household is engaged in silk weaving, silk worm raising, cloth weaving, charcoal making, and collecting or cutting firewood. The measure of income from local factories includes wages in the last three months earned at nearby factories or towns in districts such as Nang Rong, Non Suwan, Chamni or Chalaermprakit. Animals raised for sale or barter include cows, water buffalo, ducks, chickens and fish. The variable is measured as an indicator of whether the household raised one or more of these animal types. In terms of income expenditures, the use of paid labor for harvesting rice, cassava, and sugar cane and whether the household uses pesticides or herbicides in the 1999-2000 growing season are measured as separate dummy variables.

Since monetary values of assets and income are not available in the Nang Rong data, I create an index of household resources in order to develop a comprehensive picture of wealth. I combine measures of consumer durables and characteristics of the dwelling unit following work by Filmer and Prichett (2001). The index uses the first principal component as a weight for an additive index of assets. ${ }^{6}$ Since some of the assets are measured at the nominal level, I use a polychoric principal components

${ }^{6}$ Asset measures include the number of televisions, VCRs, cell phones, refrigerators, washing machines, sewing machines, itans (agricultural trucks), bicycles, motorcycles, and cars/trucks/pickups owned by the household. I also include measures for whether the dwelling unit has glass paned windows or bug screens or is one or two stories tall, and whether the household cooks with electricity or gas. 
procedure (seeKolenikov and Angeles, 2004). Using the raw index, I group households into wealth tertiles (i.e., top third, middle third, bottom third). ${ }^{7}$

\section{Analytical Approach}

To relate remittance propensity (i.e., whether monetary or in-kind goods were received by the household) measures to a set of independent and control variables, I use a recursive multivariate probit model. The model can be written:

$$
\begin{aligned}
& y_{1 i}^{*}=\beta_{10}+\delta_{1} y_{3 i}+\sum_{h=1}^{p} \beta_{1 h} x_{1 h i}+u_{1 i} \\
& y_{2 i}^{*}=\beta_{20}+\delta_{2} y_{3 i}+\sum_{h=1}^{p} \beta_{2 h} x_{2 h i}+u_{2 i} \\
& y_{3 i}{ }^{*}=\gamma_{30}+\sum_{r=1}^{q} \gamma_{3 r} z_{3 r i}+u_{3 i}
\end{aligned}
$$

Where for $j=1, \ldots, 3$ equations and $i=1, \ldots, N$ observations, $y_{j i}^{*}$ are unobserved latent variables. We observe $y_{j i}=1$ if $y_{j i}{ }^{*}>0$ and $y_{j i}=0$ otherwise; $y_{1 i}$ and $y_{2 i}$ represent the effect of monetary and in-kind remittances, respectively. $\beta_{j 0, p}$ are probit coefficients for exogenous variables $x_{j p} . \delta_{j}$ represent coefficient estimates for the effect of the skipped generation household $\left(y_{3 i}\right)$ in the remittance equations. $\gamma_{30, q}$ are probit coefficients for exogenous variables $Z_{3 q}$ in the skipped generation equation. The error terms $u_{j i}$ follow a multivariate normal distribution with mean zero and variance covariance matrix $\Sigma$, give by:

$$
\Sigma=\left(\begin{array}{ccc}
1 & \rho_{12} & \rho_{13} \\
\rho_{21} & 1 & \rho_{23} \\
\rho_{31} & \rho_{32} & 1
\end{array}\right)
$$

${ }^{7}$ The procedure uses all Nang Rong households in sample villages to construct the index, while only households included in the analytical sample are included in the analysis. Therefore, the proportion of households in Table 1 does not conform exactly to the expected tertile breakdown. 
$\rho_{j k}$ is the correlation coefficient between $u_{j}$ and $u_{k}\left(j, k=1,2,3 ; j^{1} k\right)$. I estimate the model using Stata's mvprobit command, which uses simulated maximum likelihood (SML) using the Geweke-Hajivassiliour-Keane(GHK) simulator to evaluate the multivariate normal distribution (see Cappellari and Jenkins, 2003 for details).

Regarding the amount sent, many of the households did not receive any remittances. Therefore, their records are zero-censored. To deal with this situation, I use a Tobit regression model. To deal with the endogeneity of the skipped generation household structure in the remittance amount equation, I follow a similar procedure to the one outlined earlier. I estimate a recursive mixed process model, in which I simultaneously estimate a tobit equation of remittance amount and a probit equation of the determinants of the skipped generation household. Once again, the skipped generation household variable is included on the right-hand side of the remittance equation. The model is written:

$$
\begin{aligned}
& y_{1 i}^{*}=\beta_{10}+\delta_{1} y_{2 i}+\sum_{h=1}^{p} \beta_{1 h} x_{1 h i}+u_{1 i} \\
& y_{2 i}^{*}=\gamma_{20}+\sum_{r=1}^{q} \gamma_{2 r} z_{2 r i}+u_{2 i}
\end{aligned}
$$

Here $y_{1 i}^{*}$ and $y_{2 i}^{*}$ represent the effect of amount remitted and the skipped generation household, respectively. The observed variable $y_{1 i}$ equals $y_{1 i}{ }^{*}$ when $y_{1 i}{ }^{*}$ is $>0$, but $y_{1 i}=0$ when $y_{1 i}{ }^{*} \leq 0$ (Tobin 1958, Wooldridge 2006). All other variables and parameters are similar to those in the earlier model. This routine also uses simulated maximum likelihood and the GHK simulator (see Roodman, 2007 for details).

To determine the magnitude of the effect of skipped generation household structure in the remittance equations, I calculate micro-simulated predicted probabilities for the probit equations and the expected value that the dependent variable is greater than zero for the tobit equation. I calculate two separate quantities. For the first, I constrain every household to be a non-skipped generation household. For the second, I constrain them all to be skipped generation households. I then compare the difference between the two average values, which shows the magnitude of the effect of the skipped generation variable. To account for the clustering of households in villages and for any unobserved heterogeneity at the household-level, I use robust standard errors that correct for these issues (see White, 1980). 
TABLE 1

Descriptive Statistics for All Variables, Nang Rong Households in 2000

\begin{tabular}{|c|c|c|}
\hline Variable & Mean & Std Dev \\
\hline \multicolumn{3}{|l|}{ Remittances } \\
\hline Household Received Monetary Remittances & 0.38 & 0.49 \\
\hline Household Received In-Kind Remittances & 0.25 & 0.43 \\
\hline Amount of Monetary Remittances Sent (baht) & 5307.26 & 11595.52 \\
\hline \multicolumn{3}{|l|}{ Household Demographics } \\
\hline Skipped generation household & 0.13 & 0.34 \\
\hline Members age 13 or Younger (count) & 1.03 & 0.99 \\
\hline Members age 14-49 years (count) & 2.11 & 1.33 \\
\hline Males (count) & 1.02 & 0.87 \\
\hline Females (count) & 1.09 & 0.80 \\
\hline Members age 50 and older (count) & 0.96 & 0.87 \\
\hline Males (count) & 0.43 & 0.51 \\
\hline Females (count) & 0.53 & 0.56 \\
\hline Number of Migrants (count) & 1.74 & 1.85 \\
\hline Married, Male (count) & 0.57 & 0.89 \\
\hline Married, Female (count) & 0.44 & 0.78 \\
\hline Unmarried, Male (count) & 0.34 & 0.63 \\
\hline Unmarried, female (count) & 0.27 & 0.56 \\
\hline \multicolumn{3}{|l|}{ Household Economy } \\
\hline Married Women Using Contraceptives (count) & 0.33 & 0.50 \\
\hline Participates in Cottage Industry & 0.84 & 0.37 \\
\hline Wage Income from Local Factories (baht) & 1076.46 & 5119.53 \\
\hline Owns Store, Market Stall, or Car for Peddling Goods & 0.07 & 0.26 \\
\hline Raises Animals for Sale or Barter & 0.44 & 0.50 \\
\hline Grow Rice & 0.76 & 0.43 \\
\hline Grow Cassava & 0.08 & 0.27 \\
\hline Uses Paid Labor for Rice, Cassava, or Sugar Cane Harvest & 0.46 & 0.50 \\
\hline Uses Pesticide or Herbicide & 0.26 & 0.44 \\
\hline Amount of Land Used for Farming (in Wah) & 6458.14 & 8996.31 \\
\hline \multicolumn{3}{|l|}{ Position in Household Wealth Distribution } \\
\hline Bottom Third & 0.31 & 0.46 \\
\hline Middle Third & 0.34 & 0.47 \\
\hline Top Third & 0.35 & 0.48 \\
\hline Ever Lost Crops due to Flooding or Drought & 0.61 & 0.49 \\
\hline $\mathrm{N}$ & \multicolumn{2}{|c|}{6801} \\
\hline
\end{tabular}

\section{Results}

Table 1, which shows descriptive statistics for all variables, reveals that 38 percent of all households received money, 25 percent received in-kind 
remittances, and the average monetary amount was approximately 5,307 baht (about 133 USD). Thirteen percent of households have skipped generation structures. Qualitative interviews shed some light on the internal dynamics of skipped generation households. They confirm that during the parents' absence, maternal grandparents, especially the maternal grandmother, assume primary care responsibilities for the children.

The majority of interviewees ( 90 percent) indicated that grandmothers are involved in several facets of care giving, including cooking for their grandchildren, washing their clothes, playing with them, taking them to school in the morning, and sometimes bathing them (depending on the age of the child). Grandfathers and aunts also help the grandmother in providing care, by doing such things as taking children to the public health center to get vaccinations. While grandmothers are largely responsible for taking care of their grandchild's well-being, parents are usually responsible for taking care of financial aspects of the children's needs. The following interview with a maternal grandmother taking care of her 10-year old granddaughter exemplifies a typical caretaking arrangement:

Interviewer: I will ask you about "Aing." So she is 10 years old and studying now?

Grandmother: Yes, when the semester ends she'll be in grade 5 .

Interviewer: Who pays for her school fees?

Grandmother: Her mother.

Interviewer: Do you cook for her?

Grandmother: Yes; and I have to prepare some rice for her to eat at school.

Interviewer: On the weekend do you cook?

Grandmother: Yes

Interviewer: Who pays for her clothes?

Grandmother: Her mother provides them.

Interviewer: Who takes her to see the doctor if she is sick?

Grandmother: If it's minor, I will do it, but if it isn't, her aunt will handle it.

Only 11 villagers (26 percent) offered reasons for why children cannot stay at their parents' destination. They said that many parents move to cities, which are expensive places to live. Typically both parents work long hours, and even if they share a room with other people, no one has time to care for children. The cost of hiring a baby sitter is usually prohibitive, and leaving children in rural areas is more affordable. Villagers also expressed a distrust of non-relative childcare.

About half of the villagers described a familiar life course pattern followed by many young people. Before they become parents, young people migrate to find work after completing primary school. While in their 
twenties, they often find a marriage partner at the destination. When women become pregnant, some return to rural origin villages to give birth, in part because of the expense of delivering a baby in an urban hospital. Mothers usually stay with their baby for three months, the maximum time Thai labor laws grant for maternity leave. Afterwards, mothers typically return to work in the city, perhaps joining their husband. Parents rarely see their children except on holidays like Songkran day, (the Thai New Year), or special occasions like Election day. Children seldom visit their parents in migration destinations. Separation from parents can be lengthy, at times lasting the duration of the childhood of the offspring.

Table 2 shows the results of regression models for whether the household received monetary or in-kind remittances. Results suggest that the skipped generation household structure, net of several other household variables, is a significant determinant of receipt of monetary and in-kind remittances as well as monetary remittance amount. The skipped generation pattern is positively related to each type of remittance. Predicted probabilities (not shown in table) indicate that the probability of receiving remittances changes from 48 percent to 34 percent for non-skipped generation and skipped-generation households, respectively (a difference of 14 percentage points). For in-kind remittances, the analogous change is from 23 percent to 30 percent, a seven percent difference.

Qualitative data suggest that remittance money from parents was used to offset the costs of basic living and educational expenses. The need for cash drives many parents to leave their children behind. Frequently, having only one target earner does not provide sufficient money for the household. An interview with a grandmother illustrates the division of labor involving parents and grandparents:

Interviewer: Is it a common thing that locals here usually go to work in Bangkok and leave their children with grandparents?

Grandmother: Mostly, yes. They leave to work.

Interviewer: Why doesn't one parent go to work alone while the other parent looks after the child here?

Grandmother: It is necessary for them to earn more money...

Interviewer: Do you know what the cause [of this situation] is?

Grandmother: I think the cause is economic....

Interviewer: Did you bring up your daughter yourself?

Grandmother: Yes.

Interviewer: So why don't parents bring up their own children also? Grandmother: They have no time. It can't be helped. They support me by sending me some money to pay for expenses. I think I'm like an employee. 


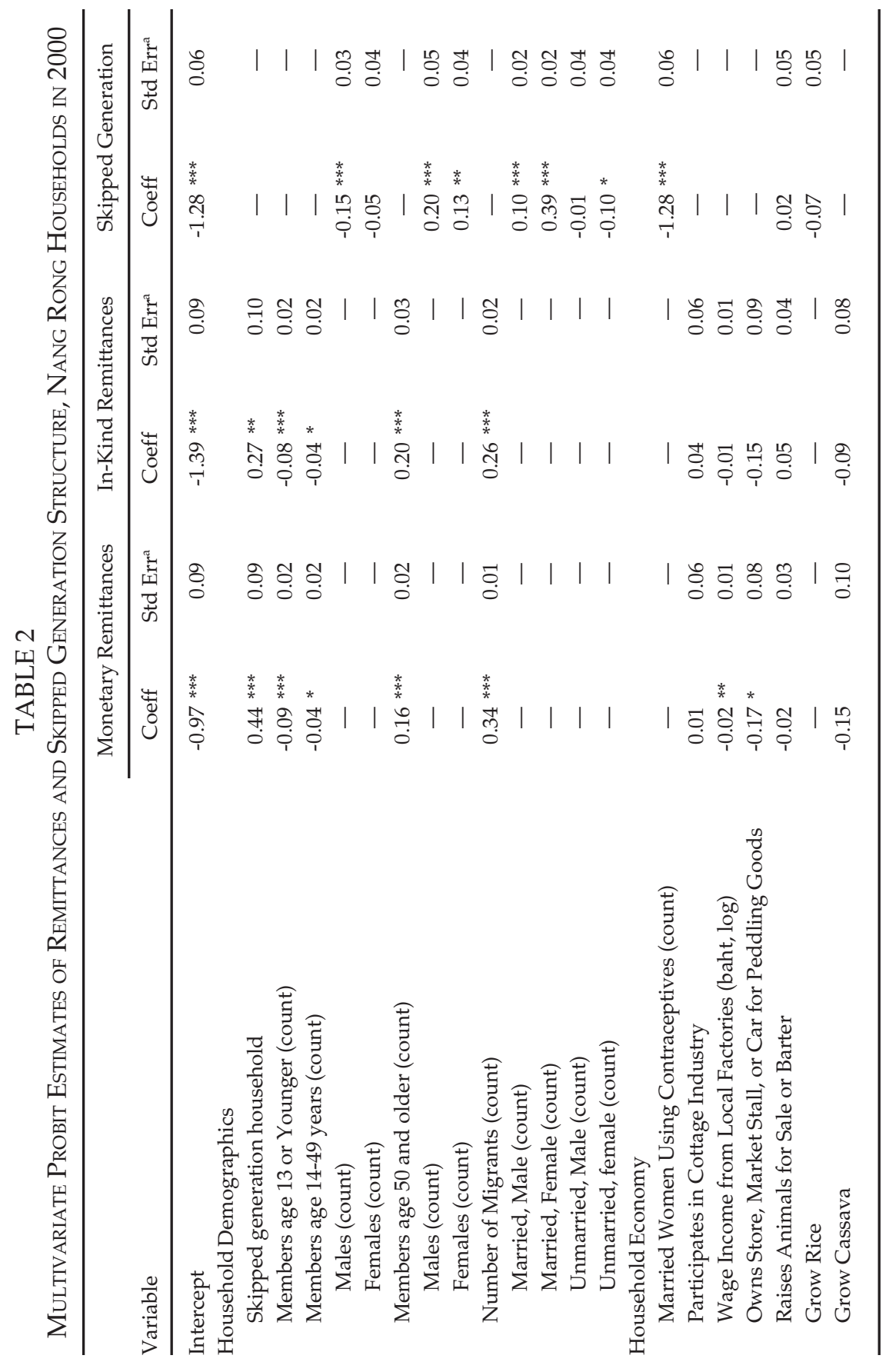




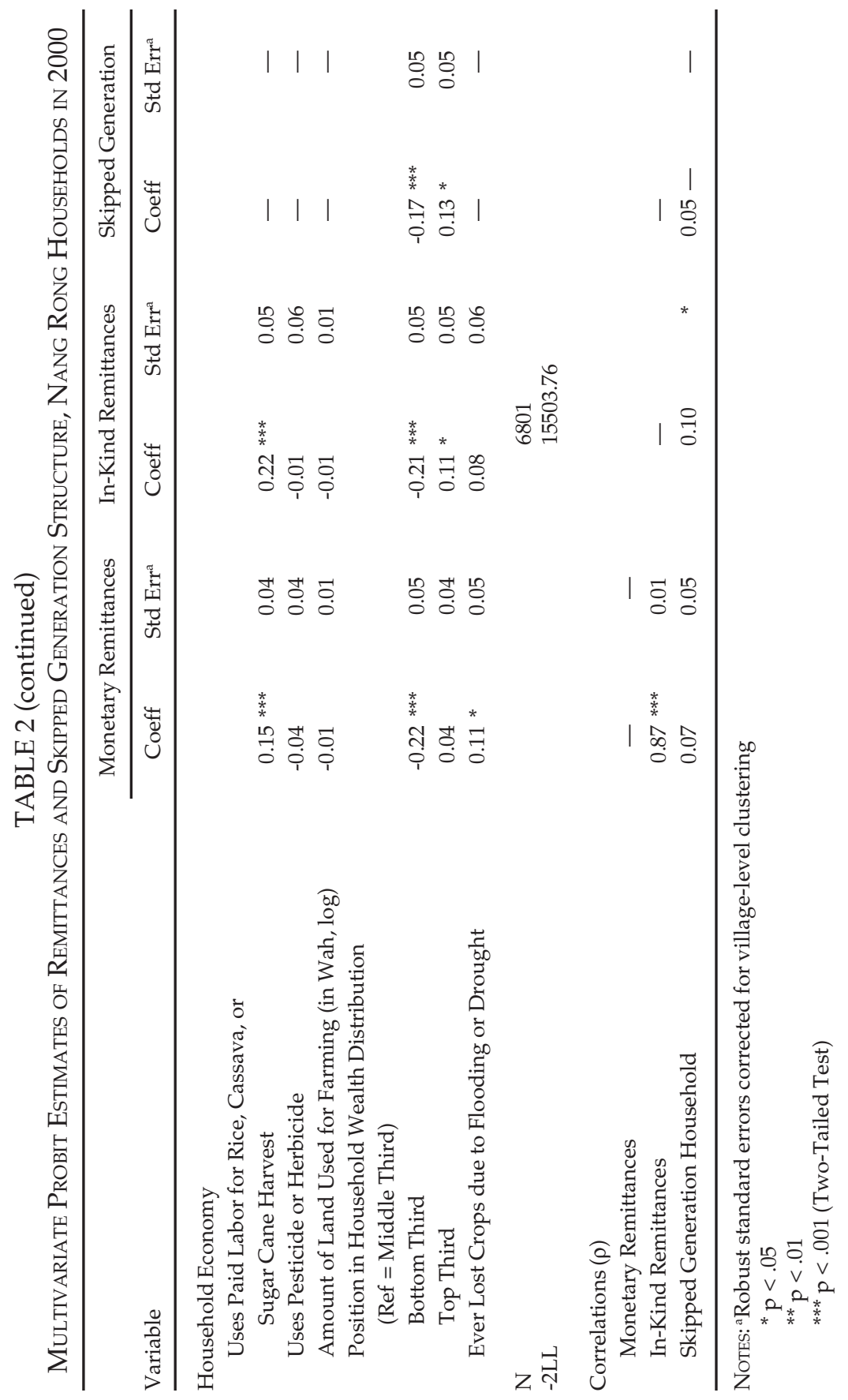


Additional descriptive statistics from the quantitative data (not shown in table) indicate that remittances from parents are common. Considering the universe of all children (age 13 or younger) residing in the village, approximately eleven percent of them have both parents in migration destinations outside of Nang Rong villages. The majority of parents, 73 percent, live in the same broad migration destination. ${ }^{8}$ Of the cases for which remittance data are available, ${ }^{9}$ the data suggest that money, food and clothes are the most common forms of remittances sent to the household. Mothers are more likely to send each of these (81 percent send money; 46 percent, clothes; 46 percent, food) than fathers (67 percent sent money; 33 percent, clothes; 34 percent, food).

Returning to results from the models, several of the control variables are also significant. I now turn to those variables. Interestingly, as the number of young people (age 13 or younger) in the household increases, the likelihood of the household receiving any money or in-kind goods decreases. Although some of the children measured by this variable live in a skipped generation household, many of these children have one or both parents living in them. Therefore, migrants may be less willing to provide money or support to children of other family members. Taken together, these results suggest that remittances are not affected by children per se, but by the children's living situation, which is likely to be related to payment for the exchange of services.

As the number of household migrants increases, so does the likelihood of receiving both types of remittances. This effect is expected. Having more migrants increases the chance that the origin household receives remittances. The only other significant demographic effect is for the number of older household members (age 50 and older) on the likelihood of sending remittances. This effect may be related to filial support of aging parents. The effects of variables measuring alternative forms of cash flow are generally unrelated to the likelihood of receiving either money or in-kind remittances. The only exceptions are ownership of a store, market stall or car for peddling goods, which both havenegative effects on receiving monetary remittances.

\footnotetext{
${ }^{8}$ The Nang Rong data only contain information on whether the migration destination is in a particular Nang Rong village, district, province or country (whatever is relevant to the particular migrant).

${ }^{9}$ As mentioned previously, not everyone who migrated from the household is defined as a migrant in the data set. Therefore, not everyone has remittance data. Given that maternal relatives usually care for the children of absent parents, mothers' migration experiences are more likely to be measured than fathers' experiences. The analysis of remittance for this portion of the paper is based on data from 555 mothers and 236 fathers.
} 
These ventures may generate enough money that the household does not need remittances. Also, using paid labor for crop harvesting has a positive effect on the propensity to receive both types of remittances, perhaps indicating that households having a need for income to pay workers have a greater capacity to extract money from migrants.

Regarding physical capital, households in the bottom third of the wealth distribution were less likely to receive money and goods compared to those in the middle third of the distribution. Their disadvantaged position probably makes it difficult for migrants from these households to get the education needed to find adequate jobs that pay them sufficiently to be able to send money back to their origin household. Households in the top third of the wealth distribution are more likely to get in-kind remittances. Finally, households that ever lost crops due to flooding or drought, an indication of risk involved in agriculture, are also more likely to receive monetary remittances.

Turning to the equation predicting the skipped generation structure, as the number of older people in the household increases (both men and women), so does the probability of the skipped generation structure. Perhaps these individuals are grandparents who care for their grandchildren in their parents' absence. The number of working age males is negatively related to the skipped generation structure. As expected, the number of married migrant men and women increases the likelihood of a skipped generation household. Conversely, the number of unmarried females decreases its likelihood. The measure of contraceptive use is also significant and in the expected negative direction. Wealth effects reveal that the skipped generation structure is more common among wealthier households. Compared to those in the middle of the wealth distribution, those at the bottom have a lower likelihood of exhibiting the skipped generation structure, while those at the top have a higher likelihood.

Correlation coefficients indicate that the monetary and in-kind remittance equations are highly correlated $(r=.87)$, and this correlation is statistically significant. Thus, these models should not be estimated as independent equations. Also, the skipped generation equation is significantly correlated with the in-kind remittance effect, although the correlation is not high $(r=.10)$.

Table 3 shows results for the amount of money received by the household. Contrary to expectations, skipped generation households receive less money, on average, than non-skipped generation households. The expected value that the amount of remittances sent is greater than zero (not shown in table) is 15,710.03 baht for skipped generation households, and 12,262.39 baht for non-skipped generation households, a difference of 3,447.64 baht (about 86 USD). Thus, although skipped-generation households are more 


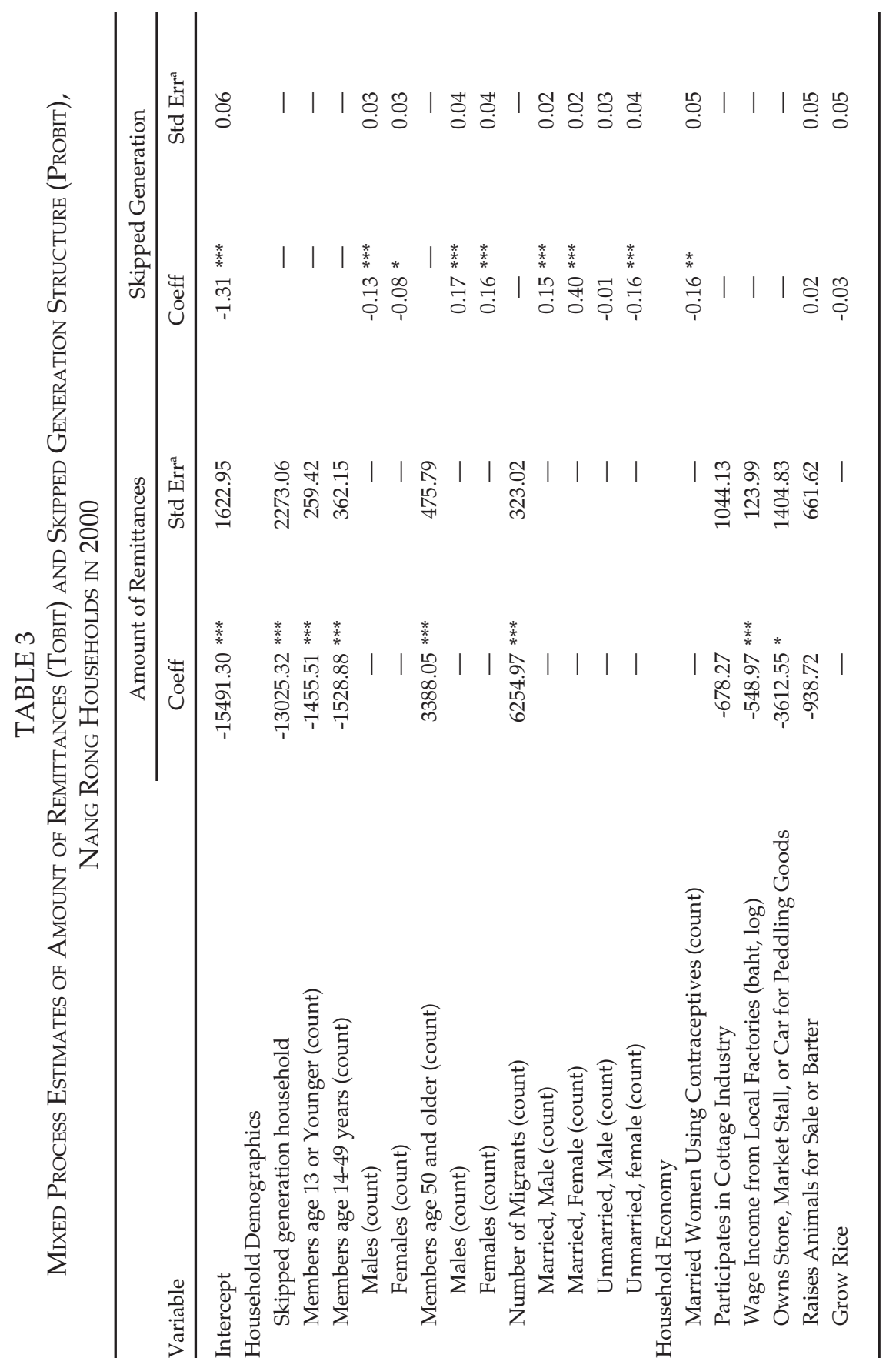




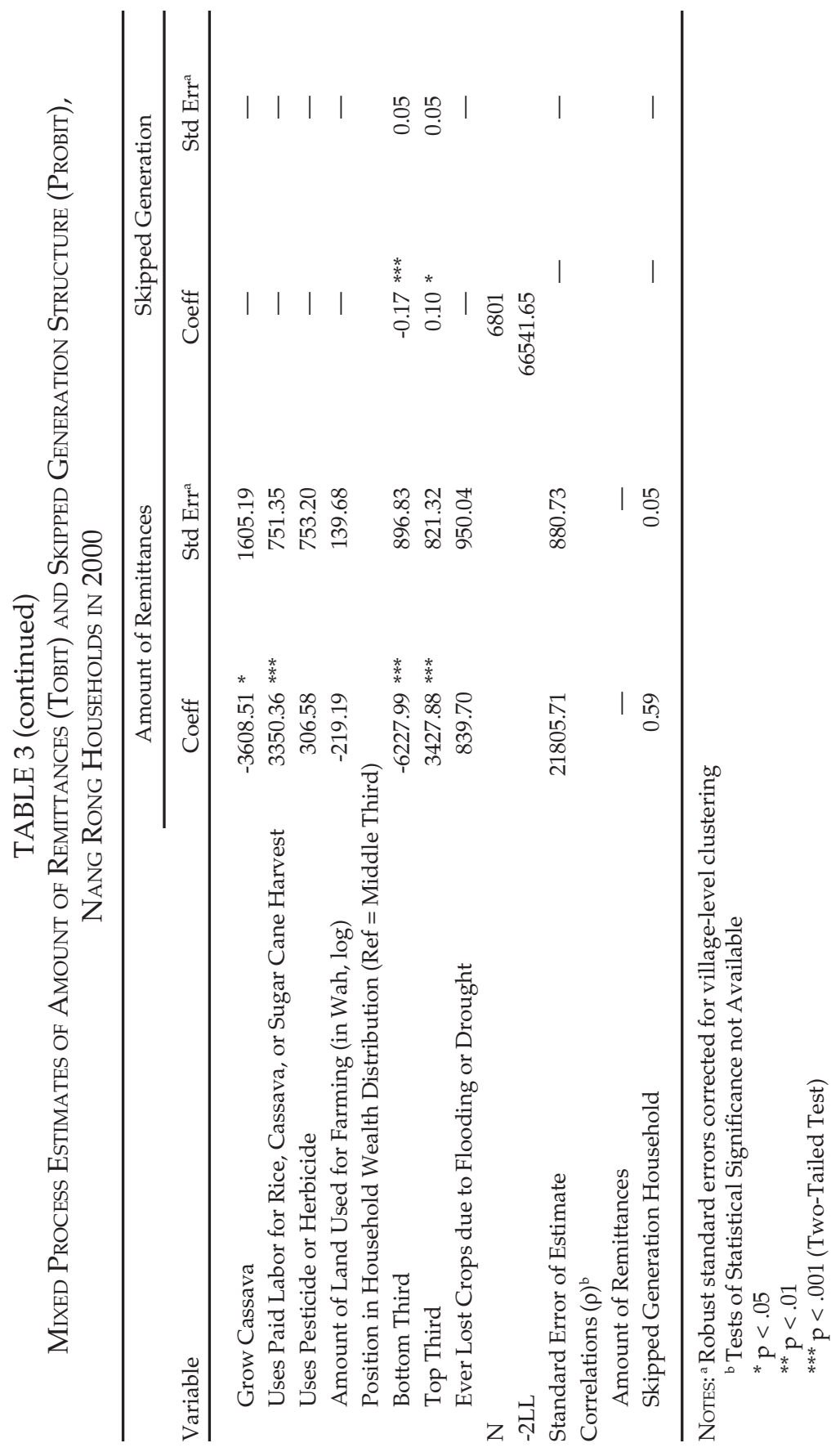


likely to receive monetary remittances, they receive lower amounts. This may suggest that other motivations, such as risk reduction, investment or filial support are more significant determinants of remittance amount.

The effects of other variables are largely consistent with earlier results. Demographic counts of younger and working-age household members are negatively related to the amount received, and the number of migrants is positively related to this outcome. Indications of alternative forms of money-generating activities such as local factory labor, store ownership and cassava cultivation are all negatively related to the amount received. The use of paid labor for harvesting is again positively related to amount received. Households at the bottom third of the wealth distribution receive lower amounts relative to those in the middle tertile, while those at the top receivehigher amounts. Also, skipped generation equation variables largely have similar effects.

Tables 4 and 5 contain results from the sensitivity analysis using a measure of past remittances. Recall that this sample is limited to households having records on all three data panels. Although results for many variables are robust across these models and the models using the larger analytical sample, the effect of the skipped generation variable on monetary remittances is not significant. It is unclear whether this disparity is due to differences in model specification or to differences in sample. Further analysis, (available upon request) in which the effect of prior remittances was excluded from the model using the more limited sample, reveals that the skipped generation effect is also non-significant. Thus, differences in sampling alone could account for the difference. However, this is not to say that prior remittance has no effect as well. In any event, these results call into question the finding that the skipped generation household is more likely to receive monetary remittances.

\section{Conclusion}

In this paper, I investigate the relationship between remittances and the skipped generation household as an indication of exchange of money for services. The setting is Nang Rong, Thailand, a rural developing region undergoing substantial social, economic and demographic changes in the last several decades. Results show that various measures of remittances (i.e.,in-kind remittances and the amount sent) are significantly related to the skipped generation household structure, net of controls for household demographics and the household economy. Results hold even after the endogeneity of the skipped generation household in the remittance equations is taken into account. 
TABLE 4

Multivariate Probit Estimates of Remittances and

Skipped Generation Structure, Sensitivity Analysis for Prior Remittances

\begin{tabular}{|c|c|c|c|c|c|c|}
\hline \multirow[b]{2}{*}{ Variable } & \multicolumn{2}{|c|}{$\begin{array}{l}\text { Monetary } \\
\text { Remittances }\end{array}$} & \multicolumn{2}{|c|}{$\begin{array}{c}\text { In-Kind } \\
\text { Remittances }\end{array}$} & \multicolumn{2}{|c|}{$\begin{array}{l}\text { Skipped } \\
\text { Generation }\end{array}$} \\
\hline & Coeff $\subseteq$ & StdErra & Coeff & StdErr ${ }^{a}$ & Coeff & Std Erra \\
\hline $\begin{array}{l}\text { Intercept } \\
\text { Household Demographics }\end{array}$ & $-0.63^{* * *}$ & 0.10 & $-1.14^{* * *}$ & 0.10 & $-1.12^{* * *}$ & 0.09 \\
\hline $\begin{array}{l}\text { Skipped generation household } \\
\text { Members age } 13 \text { or }\end{array}$ & 0.21 & 0.13 & $0.29 *$ & 0.12 & - & - \\
\hline Younger (count) & $-0.07^{* * *}$ & 0.02 & -0.04 & 0.03 & - & - \\
\hline Members age $14-49$ yrs. (count) & $-0.08^{* * * *}$ & 0.02 & $-0.07^{* * *}$ & 0.02 & - & - \\
\hline Males (count) & - & - & - & - & $-0.19^{* * *}$ & 0.03 \\
\hline Females (count) & - & - & - & - & $-0.09 *$ & 0.04 \\
\hline \multicolumn{7}{|l|}{ Members age 50} \\
\hline and older (count) & $0.09^{* *}$ & 0.03 & $0.12^{* * *}$ & 0.03 & - & - \\
\hline Males (count) & - & - & - & - & 0.10 & 0.05 \\
\hline Females (count) & - & - & - & - & 0.06 & 0.05 \\
\hline Number of Migrants (count) & $0.26^{* * *}$ & 0.02 & $0.20^{* * *}$ & 0.02 & - & - \\
\hline Married, Male (count) & - & - & - & - & $0.10^{* * *}$ & 0.03 \\
\hline Married, Female (count) & - & - & - & - & $0.40^{* * *}$ & 0.02 \\
\hline Unmarried, Male (count) & - & - & - & - & -0.04 & 0.04 \\
\hline Unmarried, female (count) & - & - & - & - & $-0.12^{* *}$ & 0.04 \\
\hline \multicolumn{7}{|l|}{ Household Economy } \\
\hline $\begin{array}{l}\text { Amount of Montary Remittances } \\
\text { Received in } 1994 \text { (in 1,000 baht) } \\
\text { Married Women Using }\end{array}$ & $0.02^{* * *}$ & 0.003 & $0.01^{* * *}$ & 0.003 & - & - \\
\hline Contraceptives (count) & - & - & - & - & $-0.13^{*}$ & 0.06 \\
\hline & \multicolumn{5}{|c|}{ Wage Income from Local } & - \\
\hline Factories (baht, log) & $-0.02 *$ & 0.01 & 0.01 & 0.01 & - & - \\
\hline \multicolumn{7}{|l|}{ Owns Store, Market Stall, or } \\
\hline Car for Peddling Goods & -0.16 & 0.10 & -0.08 & 0.09 & - & - \\
\hline Raises Animals for Sale or Barter & -0.02 & 0.04 & 0.08 & 0.04 & 0.04 & 0.06 \\
\hline Grow Rice & - & - & - & - & -0.07 & 0.06 \\
\hline Grow Cassava & -0.14 & 0.10 & -0.06 & 0.08 & - & - \\
\hline $\begin{array}{l}\text { Uses Paid Labor for Rice, Cassava, } \\
\text { or Sugar Cane Harvest }\end{array}$ & $0.11^{*}$ & 0.05 & $0.15^{* *}$ & 0.05 & - & - \\
\hline Uses Pesticide or Herbicide & -0.01 & 0.05 & 0.06 & 0.06 & - & - \\
\hline \multicolumn{7}{|l|}{ Amount of Land Used for } \\
\hline Farming (in Wah, log) & -0.01 & 0.01 & -0.01 & 0.01 & - & - \\
\hline \multicolumn{7}{|l|}{ Position in Household Wealth } \\
\hline Bottom Third & $-0.19 * * *$ & 0.05 & $-0.20^{* * *}$ & 0.05 & $-0.16^{* *}$ & 0.06 \\
\hline Top Third & 0.05 & 0.05 & 0.08 & 0.06 & $0.17^{* *}$ & 0.06 \\
\hline \multicolumn{7}{|l|}{ Ever Lost Crops due to Flooding } \\
\hline $\mathrm{N}$ & & & 4430 & & & \\
\hline$-2 \mathrm{LL}$ & & & 385.64 & & & \\
\hline \multicolumn{7}{|l|}{ Correlations (r) } \\
\hline Monetary Remittances & - & - & & & & \\
\hline In-Kind Remittances & $0.85^{* * *}$ & 0.01 & - & - & & \\
\hline Skipped Generation Household & $0.20^{* * *}$ & 0.06 & 0.11 & 0.06 & - & - \\
\hline
\end{tabular}

NoтеS: ${ }^{a}$ Robust standard errors corrected for village-level clustering ${ }^{*} \mathrm{p}<.05,{ }^{* *} \mathrm{p}<.01,{ }^{* * *} \mathrm{p}<.001$ (Two-Tailed Test) 
TABLE 5

Mixed Process Estimates of Amount of Remittances (Tobit) and Skipped Generation Structure (Probit), Sensitivity Analysis for Prior Remittances

\begin{tabular}{|c|c|c|c|c|}
\hline \multirow[b]{2}{*}{ Variable } & \multicolumn{2}{|c|}{$\begin{array}{l}\text { Amount of } \\
\text { Remittances }\end{array}$} & \multicolumn{2}{|c|}{$\begin{array}{l}\text { Skipped } \\
\text { Generation }\end{array}$} \\
\hline & Coeff & Std Err ${ }^{\mathrm{a}}$ & Coeff & Std Erra \\
\hline Intercept & $-8923.95^{* * *}$ & 1712.22 & $-1.13^{* * *}$ & 0.09 \\
\hline \multicolumn{5}{|l|}{ Household Demographics } \\
\hline Skipped generation household & $-13403.73^{* * *}$ & 2511.12 & - & - \\
\hline Members age 13 or Younger (count) & $-1084.28^{* * *}$ & 287.88 & - & - \\
\hline Members age $14-49$ years (count) & $-2028.08^{* * *}$ & 430.11 & - & - \\
\hline Males (count) & - & - & $-0.17^{* * *}$ & 0.03 \\
\hline Females (count) & - & - & $-0.13^{* * *}$ & 0.04 \\
\hline Members age 50 and older (count) & $1363.09 * *$ & 476.98 & - & - \\
\hline Males (count) & - & - & 0.06 & 0.05 \\
\hline Females (count) & - & - & 0.08 & 0.05 \\
\hline Number of Migrants (count) & $4735.81^{* * *}$ & 342.27 & - & - \\
\hline Married, Male (count) & - & - & $0.15^{* * *}$ & 0.02 \\
\hline Married, Female (count) & - & - & $0.40^{* * *}$ & 0.02 \\
\hline Unmarried, Male (count) & - & - & -0.04 & 0.04 \\
\hline Unmarried, female (count) & - & - & $-0.16^{* * *}$ & 0.04 \\
\hline \multicolumn{5}{|l|}{ Household Economy } \\
\hline \multicolumn{5}{|l|}{ Amount of Montary Remittances } \\
\hline Received in 1994 (in 1,000 baht) & $317.23 * * *$ & 32.93 & - & - \\
\hline Married Women Using Contraceptives (count) & - & - & $-0.13^{*}$ & 0.06 \\
\hline Participates in Cottage Industry & -356.35 & 1066.13 & - & - \\
\hline Wage Income from Local Factories (baht, log) & $-470.47^{* * *}$ & 133.03 & - & - \\
\hline \multicolumn{5}{|c|}{ Owns Store, Market Stall, or Car } \\
\hline for Peddling Goods & -2529.76 & 1624.95 & - & - \\
\hline Raises Animals for Sale or Barter & -848.10 & 794.28 & 0.04 & 0.05 \\
\hline Grow Rice & - & - & -0.02 & 0.06 \\
\hline Grow Cassava & $-3756.85^{*}$ & 1594.88 & - & - \\
\hline \multicolumn{5}{|l|}{ Uses Paid Labor for Rice, Cassava, or } \\
\hline Sugar Cane Harvest & $2383.26^{* *}$ & 884.08 & - & - \\
\hline Uses Pesticide or Herbicide & 951.39 & 880.83 & - & - \\
\hline \multicolumn{5}{|l|}{ Amount of Land Used for Farming } \\
\hline (in Wah, log) & -202.31 & 156.55 & - & - \\
\hline \multicolumn{5}{|l|}{$\begin{array}{l}\text { Position in Household Wealth Distribution } \\
\text { (Ref = Middle Third) }\end{array}$} \\
\hline Bottom Third & $-5691.50^{* * *}$ & 956.57 & $-0.16^{* *}$ & 0.06 \\
\hline Top Third & $3642.59 * * *$ & 947.96 & $0.14 *$ & 0.06 \\
\hline Ever Lost Crops due to Flooding or Drought & 629.67 & 1008.42 & - & - \\
\hline $\mathrm{N}$ & \multicolumn{4}{|c|}{4430} \\
\hline$-2 \mathrm{LL}$ & & 5234 & .84 & \\
\hline Standard Error of Estimate & 21098.92 & 1022.6 & - & - \\
\hline \multicolumn{5}{|l|}{ Correlations $(\rho)^{b}$} \\
\hline Amount of Remittances & - & - & & \\
\hline Skipped Generation Household & 0.61 & 0.05 & - & - \\
\hline
\end{tabular}

NOTES: aRobust standard errors corrected for village-level clustering

${ }^{b}$ Tests of Statistical Significance not Available

${ }^{*} \mathrm{p}<.05,{ }^{* *} \mathrm{p}<.01,{ }^{* * *} \mathrm{p}<.001$ (Two-Tailed Test) 
Consistent with expectations, the propensity for a household to receive remittances is positively related to having a skipped generation household structure. However, the effect of monetary remittances is questionable given the sensitivity analysis results. Contrary to expectations, skipped generation households receive lower amounts of monetary remittances compared to non-skipped generation households.

Qualitative interviews suggest that extended relatives, especially maternal grandmothers (and to a lesser extent grandfathers and aunts) take responsibility for caring for the children of absent migrants. Yet, quantitative results suggest that the skipped generation structure is not associated with the receipt of monetary remittances from migrants. Instead, remittances are more likely to come in the form of in-kind remittances, which are perhaps more suited to the specific needs of the children who are left behind.

Results contradict findings from a wider literature on inter vivos transfers, which suggest that money is exchanged for help with services (including childcare). My findings inform the literature on migrant remittances by suggesting that although extended relatives who care for the children of absent migrants may free the parental generation of the responsibility of taking care of their children (thus making it possible for parents to remain in migration destinations and to earn money), this provision of services does not benefit the origin household monetarily (at least in comparison to remittances related to other factors). Therefore, the childcare provided by extended relatives is probably not due to an exchange motive, but rather to feelings of obligation to care for their grandchildren, perhaps stemming from an altruistic orientation toward family members. Indeed, many of the interviewees expressed feeling duty bound to provide care for their grandchildren, with whom they share blood ties.

This research implies that migrating parents, despite having a few alternative childcare options, persist in relying on care from extended relatives for help with childcare during a migration spell. As developing countries like Thailand continue to transition to an urban industrial base, future generations may begin to use formal childcare located closer to their place of work. At the time of the study, formal childcare institutions were not a mature industry in Thailand, but they may come into existence as demand increases. Is it likely that the role of extended kin will diminish as new formal childcare institutions replace this more traditional form of childcare? Or will the skipped generation pattern persist where migration remains heavy and formal childcare fails to address the needs of parents?

Future research is needed to determine if industrialization will continue to attract rural workers, and if their wages will rise to the point that they can afford proper childcare at migration destinations. Further work is also needed to determine the extent to which these findings can be general- 
ized to other settings. Important questions remain regarding whether this pattern will characterize both internal migrants and international migrants, especially given the difficultly that transnational parents face in crossing international borders. This has implications for parental visitation and for the migration of children seeking family reunification.

One potential policy implication of this research is that the Thai government should provide aid and services to households having a skipped generation structure. Given that they have to take on the burden of caring for young children without the benefit of receiving substantially higher monetary remittances, older people living in these households may struggle to provide for the well-being of these children. As a consequence both the children and grandparents may suffer emotionally and materially. Work in Mexico by Dreby (2007) confirms that children experience negative consequences, such as lower school performance and psychological distress, resulting from prolonged separation from migrant parents. Moreover, grandparents sometimes have difficulty controlling the bad behavior of children who feel anxiety and disconnection due to their parents' absence.

\section{REFERENCES}

Amuedo-Dorantes, Catalina and Susan Pozo

2006 "Remittances as Insurance: Evidence from Mexican Immigrants," Journal of Population Economics, 19(2):227-254.

Becker, Gary

1993 A Treatise on the Family. Cambridge, MA: Harvard University Press.

Bernheim, B. D., A. Schleifer and L. Summers

1985 “The Strategic Bequest Motive," Journal of Political Economy, 93(6):1045-1076.

Bledsoe, C. and U.C. Isiugo-Abanihe

1989 "Strategies of Child Fosterage among Mende Grannies in Sierra Leone." In Reproduction and Social Organization in Sub-Saharan Africa. Edited by Ron Lesthaeghe. Berkeley, CA: University of California Press.

Brewster, Karin L. and Ronald R. Rindfuss

2000 "Fertility and Women's Employment in Industrialized Nations," Annual Review of Sociology, 26:271-296.

Brown, Richard P.C. and Bernard Poirine

2005 "A Model of Migrants' Remittances with Human Capital Investment and Intrafamilial Transfers," International Migration Review, 39(2):407-438. 
Cappellari, L. and S.P. Jenkins

2003 "Multivariate Probit Regression using Simulated Maximum Likelihood," The Stata Journal, 3(3):278-294.

Casper, Lynne M. and Kenneth R. Bryson

1998 "Coresident Grandparents and Their Grandchildren: Grandparent Maintained Families." Population Division Working Paper No. 26, Bureau of the Census, Washington DC, USA.

Chaippori, P.

1992 "Collective Models of Household Behavior: The Sharing Rule Approach." Paper presented at the International Food Policy Research Institute-World Bank Conference on Intrahousehold Resource Allocation: Policy Issues and Research Methods, Washington, DC, 12-14 February 1992.

Chamratrithirong, A., et al.

1995 National Migration Survey of Thailand. Nakonpathom, Thailand: Institute for Population and Social Research, Mahidol University.

Chen, Feinian, Susan E. Short and Barbara Entwisle

2000 "The Impact of Grandparental Proximity on Maternal Childcare in China," Population Research and Policy Review, 19(6):571-590.

Cox, Donald

1987 "Motives for Private Income Transfers," Journal of Political Economy, 95(3): 508-546.

Curran, Sara

2005 "Uncovering Trade, Development and Environment Linkages: The Case of Cassava in Thailand and Food in Europe, 1970-2002." Paper presented to the conference: Trading Morsels, Growing Hunger, Decimating Nature: Linking Food and Trade to Development and the Environment, Princeton Institute for International and Regional Studies, Princeton University, New Jersey, USA, 24-26 February 2005.

1995 “Gender Roles and Migration: 'Good Sons' vs. Daughters in Rural Thailand.” Seattle Population Research Center Working Paper No. 95-11, Seattle Population Research Center, University of Washington, Seattle, Washington, USA.

de la Brière, B. Sadoulet, A. de Janvry and S. Lambert

2002 "The Role of Destination, Gender, and Household Composition in Explaining Remittances: An Analysis of Dominican Sierra," Journal of Development Studies, 68(2):309328.

Degler, C.

1980 At Odds: Women and the Family in America from the Revolution to the Present. New York, NY: Oxford University Press.

Desai, Sonalde and Devaki Jain

1994 "Maternal Employment and Changes in Family Dynamics: The Social Context of Women's Work in RuralSouth India," Population and Development Review, 20(1):115136. 
Dreby, Joanna

2007 "Children and Power in Mexican Transnational Families," Journal of Marriage and Family, 69(4):1050-1064.

2006 "Honor and Virtue: Mexican Parenting in the Transnational Context," Gender and Society, 20(1):32-59.

Entwisle, Barbara et al.

1998 "Landuse/Landcover (LULC) and Population Dynamics, Nang Rong, Thailand." In People and Pixels: Using Remotely Sensed Data in Social Science Research. Edited by Diana Liverman, Emilio F. Moran, Ronald R. Rindfuss and Paul C. Stern. Washington, DC: National Academy Press.

Entwisle, B. et al.

1996 "Community and Contraceptive Choice in Rural Thailand: A Case Study of Nang Rong," Demography, 33(1):1-11.

Filmer, Deon and Lant Pritchett

2001 "Estimating Wealth Effects without Expenditure Data - or Tears: An Application to Educational Enrollments in States of India," Demography, 38(1):115-132.

Frankenberg, Elizabeth, Lee Lillard and Robert Willis

2002 "Patterns of Intergenerational Transfers in Southeast Asia," Journal of Marriage and the Family, 64(3):627-641.

Godley, Jenny

2001 "Kinship Networks and Contraceptive Choice in Nang Rong, Thailand," International Family Planning Perspectives, 27(1):4-10.

Goldstein, Sidney

1987 "Forms of Mobility and their Policy Implications: Thailand and China Compared," Social Forces, 65(4):915-942.

Greene, William

2003 Econometric Analysis. $5^{\text {th }}$ edition. Upper Saddle River, NJ: Prentice Hall.

Hashimoto, A.

1991 "Living Arrangements of the Aged in Seven Developing Countries: A Preliminary Analysis," Journal of Cross-Cultural Gerontology, 6(4):359-382.

Hermalin, A. I., C. Roan and A. Perez

1998 The Emerging Role of Grandparents in Asia. Population Studies Center, University of Michigan, Elderly in Asia Research Report Series No. 98-52.

Hoddinot, John

1994 "A Model of Migration and Remittances Applied to Western Kenya," Oxford Economic Papers, 46(3):459-476.

Hondagneu-Sotelo, Pierrette and Ernestine Avila

1997 "I'm Here, but I'm There: The Meaning of Latina Transnational Motherhood," Gender and Society, 11(5):548-571. 
Hirsch, J.S.

2003 A Courtship after Marriage: Sexuality and Love in Mexican Transnational Families. Berkeley, CA: University of California Press.

Hull, James R.

2007 "Migration, Remittances and Monetization of Farm Labor in Subsistence Sending Areas," Asian and Pacific Migration Journal, 16(4):451-484.

International Organization for Migration (IOM)

2005 International Migration and Development: A Global Perspective. IOM Migration Research Series No. 19. Geneva: IOM.

Jampaklay, Aree

2006 "How Does Leaving Home Affect Marital Timing? An Event-History Analysis of Migration and Marriage in Nang Rong, Thailand," Demography, 43(4):711-725.

Kapur, Devesh and John McHale

2003 “Migration's New Payoff," Foreign Policy, 139(November/December):49-57.

Kolenikov, Stanislav and Gustavo Angeles

2004 The Use of Discrete Data in PCA: Theory, Simulations, and Applications to Socioeconomic Indices. MEASURE/Evaluation Project Working Paper No. WP-04-85, Carolina Population Center, Chapel Hill, North Carolina, USA.

Knodel, John and Chanpen Saengtienchai

2007 "Rural Parents with Urban Children: Social and Economic Implications of Migration on the Rural Elderly in Thailand," Population Place and Space, 13(3):193-210.

Lee, Yean-Ju

2000 "Support between Rural Parents and Migrant Children in a Rapidly Industrializing Society: South Korea." In Sharing the Wealth: Demographic Change and Economic Transfers between the Generations. Edited by A. Mason and G. Tapinos. Oxford, UK: Oxford University Press.

Lee, Yean-Ju, William L. Parish and Robert Willis

1994 "Sons, Daughters, and IntergenerationalSupport in Taiwan," The American Journal of Sociology, 99(4):1010-1041.

Lillard, Lee A. and Robert J. Willis

1997 "Motives for Intergenerational Transfers: Evidence from Malaysia," Demography, 34(1):115-134.

Limanonda, Bhassorn

1995 "Families in Thailand: Beliefs and Realities," Journal of Comparative Family Status, 26(1):67-83.

Limanonda Bhassorn and Rungratana Kowantanakul

2002 "Sustainable Urbanization and Human and Environmental Security in Asia. Final Report. Part 3. Analytical Papers. Post Nuptial Residence in Thailand: Evidence in Urban Cities in Year 2000." Research Series. National Institute of Population and Social Security Research, Tokyo, Japan. No. 304:414-435. 
Lin, I-Fen et al.

2003 "Gender Differences in Adult Children's Support of their Parents in Taiwan," Journal of Marriage and the Family, 65(1):184-200.

Massey, Douglas S. et al.

1993 "Theories of International Migration," Population and Development Review, 19(3):431466.

Phongphit, Seri and Kevin Hewison

2001 Village Life:Culture and Transition in Thailand's Northeast. Bangkok, Thailand: White Lotus Press.

Piotrowski, Martin

2008 "Migrant Remittances and Household Division: the Case of Nang Rong, Thailand," Journal of Marriage and the Family, 70(4):1074-1087.

Peterson, J.T.

1993 "Generalized Extended Family Exchange: A Case from the Philippines," Journal of Marriage and the Family, 55(9):570-584.

Pejaranonda, Chintana, Sureerat Santipaporn and Philip Guest

1995 "Rural-Urban Migration in Thailand." In Trends, Patterns, and Implications of RuralUrban Migration in India, Nepal, and Thailand. Population Studies Series No. 138. New York, NY: United Nations.

Presser, Harriet B.

1986 "Comment: Changing Values and Falling Birth Rates," Population and Development Review, 12(Supp)(86):196-200.

Richter, Kerry

1996 "Living Separately as a Child-Care Strategy: Implications for Women's Work and Family in Urban Thailand," Journal of Marriage and the Family, 58(2):327-339.

Richter, Kerry et al.

1992 Child Care in Urban Thailand: Choice and Constraint in a Changing Society. Salaya Nakhonpathon, Thailand: Institute for Population and Social Research.

Rindfuss, Ronald R.

1991 "The Young Adult Years: Diversity, Structural Change, and Fertility," Demography, 28(4):493-512.

Rindfuss, Ronald R., Karen Benjamin Guzzo and S. Philip Morgan

2003 "The Changing Institutional Context of Low Fertility," Population Research and Policy Review, 22(5-6):411-438.

Rindfuss, Ronald R. et al.

2007 "Panel Studies and Migration," Social Science Research, 36(1):374-403.

Roberts, Kenneth D.

1997 "China's 'Tidal Wave' of Labor: What Can We Learn from Mexican Undocumented Migration to the United States?," International Migration Review, 31(2):249-293. 
Roberts, Kenneth D. and Michael D. Morris

2004 "Fortune, Risk, and Remittances: An Application of Option Theory to Participation in Village-Based Migration Networks," International Migration Review,37(4):1252-1281.

Roodman, David

2007 Cmp: Stata Module to Implement Conditional (Recursive) Mixed Process Estimator. Statistical Software Components, Boston College Department of Economics.

Roos, P.A.

1985 Gender and Work: A Comparative Analysis of Industrial Societies. Albany, NY: State University of New York Press.

Salazar Parreñas, R.

2005 Children of Global Migration: Transnational Families and Gender Woes. Standford, CA: Standford University Press.

Schmalzbauer, Leah

2004 "Searching for Wages and Mothering from Afar: The Case of Honduran Transnational Families," Journal of Marriage and Family, 66(5):1317-1331.

Schroder-Butterfill, Elisabeth

2004 "Inter-Generational Family Support Provided by Older People in Indonesia," Ageing and Society, 24(4):497-530.

Secondi, Giorgio

1997 "Private Transfers in Rural China: Are Families Altruistic?," Journal of Development Studies, 33(4):487-511.

Stark, Oded

1991 The Migration of Labor. Cambridge, MA: Basil Blackwell.

1984 “Bargaining, Altruism, and Demographic Phenomena," Population and Development Review, 10(4):679-692.

Stark, Oded and Robert E.B. Lucas

1988 "Migration, Remittances, and the Family," Economic Development and Cultural Change, 36(3):465-482.

Stycos, Mayone J. and Robert H. Weller

1967 "Female Working Roles and Fertility," Demography, 4(1):210-217.

Tan, Joo Ean

2002 "Living Arrangements of Never-Married Thai Women in a Time of Rapid Social Change," Sojourn, 17(1):24-51.

Taylor, Edward J.

1999 "The New Economics of Labour Migration and the Role of Remittances in the Migration Process," International Migration, 37(1):63-87.

Taylor, J. Edward and Philip Martin

2001 "Human Capital: Migration and Rural Population Change," In Handbook of AgriculturalEconomics, Volume 1.Edited by Gardner, B.L. and Gordon C. Rausser. Amsterdam, The Netherlands: Elsevier. 
Tobin, James

1958 "Estimation for Relationships with Limited Dependent Variables," Econometrica, 26(1):24-36.

VanWey, Leah K.

2004 "Altruistic and Contractual Remittances between Male and Female Migrants and Households in Rural Thailand," Demography, 41(4):739-756.

2003 "Land Ownership as a Determinant of Temporary Migration in Nang Rong, Thailand," European Journal of Population, 19(2):121-145.

Weller, R.H.

1977 "Wife's Employment and Cumulative Family Size in the United States, 1970 and 1960," Demography, 14(1):43-65.

White, Halbert

1980 "A Heteroskedasticity-Consistent Covariance Matrix Estimator and a Direct Test for Heteroskedasticity," Econometrica, 48(4):817-838.

Wooldridge, Jeffrey

2006 Introductory Econometrics: A Modern Approach. $3^{\text {rd }}$ edition. Mason, OH: Thomson.

World Bank

2006 Global Economic Prospects 2006: Economic Implications of Remittances and Migration. Washington, DC: World Bank.

World Health Organization (WHO)

2009 "Thailand and Family Planning: An Overview." Available at http:/ /www.searo.who. int/LinkFiles/Family_Planning_Fact_Sheets_thailand.pdf, accessed on 22 January 2009.

Yang, Dean and HwaJung Choi

2007 "Are Remittances Insurance? Evidence from Rainfall Shocks in the Philippines," World Bank Economic Review, 21(2):219-248. 